\title{
Epidemiological surveillance, virulence and public health significance of Listeria spp. from drinking water
}

\author{
Pandove, G. ${ }^{1 \star}$, Sahota, P. ${ }^{1}$, Verma, S. K. ${ }^{2}$, Kirandeep ${ }^{1}$, Sharma $N^{1}$, Kaur $B^{3}$ and Vikal $Y^{3}$ \\ ${ }^{1}$ Department of Microbiology, Punjab Agricultural University, Ludhiana-141004, Punjab, India. \\ ${ }^{2}$ Department of Epidemiology and Preventive Medicine, College of Veterinary Science, Guru Angad Dev Veterinary and \\ Animal Sciences University, Ludhiana, Punjab, India. \\ ${ }^{3}$ School of Agricultural Biotechnology, Punjab Agricultural University, Ludhiana-141004,Punjab, India.
}

Accepted 9 September, 2012

\begin{abstract}
Epidemiological surveillance of drinking water from Punjab, India reported occurrence of Listeria spp. in $58.67 \%$ of Municipal Corporation (MC), $51.38 \%$ submersible pump and $12.5 \%$ hand pumps and Escherichia coli in $53.71 \%$ of MC, $29.16 \%$ submersible pump and none of samples from hand pumps. There was no positive correlation between the simultaneous occurrence of Listeria spp. and E. coli $(\mathrm{P}<$ $0.005 ; R^{2}=0.89$ ). Isolates were identified serologically and confirmed by polymerase chain reaction (PCR) amplification using specific primers targeting a 1200 bp fragment of the 16S rRNA gene. All isolates of Listeria spp. were haemolytic on $5 \%$ sheep blood agar and positive for congo dye uptake and showed multiple drug resistance, multiple antibiotic resistance (MAR) indices of 0.86 (>0.2). One isolate of Listeria spp. was molecularly identified by sequencing of 16S rRNA gene, and its gene sequence was submitted to National Center for Biotechnology Information (NCBI) under accession no. JF798637. Using this isolate, histopathological studies were carried out and It caused significant histopathological and ultrastructural alterations in experimentally infected BALB/c mice. The conventional methods cannot predict the presence of these potentially enteropathogenic microorganisms in drinking water and hence represents a serious public health concern.
\end{abstract}

Key words: Epidemiological, Listeria spp., haemolytic, serologically histopathological, multiple antibiotic resistance (MAR).

\section{INTRODUCTION}

Safe water supplies and environmental sanitation are vital for protecting the environment, improving health and alleviating poverty. Every effort should be made to achieve a drinking-water quality as safe as practicable (WHO, 2004). The World Bank estimates that $21 \%$ of communicable diseases in India are water related. Diarrhoeal diseases kill an estimated 1.8 million people each year. The highest mortality from diarrhoea is in children

*Corresponding author. Email: gpandoveg@yahoo.co.in.

Abbreviations: MC, Municipal Corporation; PCR, polymerase chain reaction; SEM, scanning electron microscope. under the age of five, highlighting an urgent need for focused interventions to prevent diarrhoeal disease in this age group. The provision of clean drinking water has been given priority in the Constitution of India, with Article 47 conferring the duty of providing clean drinking water and improving public health standards of the states in India. A total of Rs.1, 105 billion has been spent till 10th plan, on providing safe drinking water but still lack of safe and secure drinking water continues to be a major hurdle and a national economic burden (www.wateraid.org).

The spectrum of water-borne diseases is expanding, and majority of diseases once believed to be conquered are on the rise. Zoonoses are of increasing concern for human health; next to pathogens with human-to-human transmission as they pose the greatest challenges to 
ensure the safety of drinking water. Listeria spp. is an ubiquitous bacteria widely distributed in nature, lives in plant-soil environments and has been isolated from about 42 species of domestic and wild mammals and 22 species of birds, as well as fish, crustaceans, insects, sewage, water, feedstuffs, milk, cheese, meconium, feces and soil (Kirkan et al., 2006). The possible reason for occurrence of Listeria spp. in drinking water utilities may be fecal wastes from domestic animals, which may enter water system by direct contamination of the water or through seepage or surface runoff. Domestic and wild animals contaminate water by defecation in unprotected surface water, through runoff and as a result of seepage of water through soil result in contamination of ground water and may result in the incident of Listeria spp. in ground water.

The clinical syndromes of the disease caused by pathogenic species of Listeria in human include invasive listeriosis, non-invasive gastrointestinal disease, as well as local skin and eye symptoms (Maijala et al., 2001). Invasive listeriosis causes meningoencephalitis, encephalitis, sepsis, and abortions, and has a high mortality rate (20 to $30 \%)$. On the other hand, non-invasive listeriosis causes fever, diarrhea, muscle pain, headache, nausea, vomiting and abdominal pain in healthy adults (Lunden et al., 2004). Listeria species were generally reported to be susceptible to most antibiotics (Li et al., 2007) but more recently, reports of antibiotic resistance in Listeria spp. have been published (Arslan and Ozdemir, 2008; Conter et al., 2009). Thus, more information is required on the pattern of dispersion of antibiotic resistance among Listeria spp.

Most study on the isolation, virulence and antimicrobial susceptibility profiles of Listeria species focus almost exclusively on clinical and/or food isolates, with little information on water borne listeriosis. Keeping all this in view, the present research was proposed with the objecttive to study epidemiology, virulence and antibiotic susceptibility of Listeria spp. isolates in drinking water.

\section{MATERIALS AND METHODS}

\section{Research site description}

Ludhiana is the largest city in Punjab, India, both in terms of area and population. The city is spread over an area of $159.37 \mathrm{sq} \mathrm{km}$ and accommodates approximately 14.00 lacs population. The city has been divided into 70 municipal wards, in which only 31 municipal wards report slums. The rapid and immense industrialization of Ludhiana city has resulted in the emergence of several slum colonies in and around the city.

\section{Sample collection, transport and storage}

The drinking water samples were collected from endemic gastroenteritis affected suburbs of Ludhiana with migratory population. The samples were treated with sodium thiosulfate to inactivate any residual halogen compound present in the sample $\left(\mathrm{Na}_{2} \mathrm{~S}_{2} \mathrm{O}_{3}\right.$ concentration of $18 \mathrm{mg} / \mathrm{l}$ neutralizes up to $5 \mathrm{mg}$ of free (residual) chlorine per litre). The samples containing high concentration of zinc and copper were treated with EDTA at concentration of 372 $\mathrm{mg} / \mathrm{l}$ to reduce metal toxicity (APHA, 1989). The samples were analyzed within $24 \mathrm{~h}$ by transporting in refrigerated container at $4^{\circ} \mathrm{C}$.

\section{Microbiological analysis of water samples}

A total of 418 samples (Municipal corporation 242, submersible pump 144 and hand pump 32) from endemic area of gastroenteritis infected area were analysed by the standard methods [Bureau of Indian Standards, IS-10500-1991, New Delhi, India; www.indiawaterportal.org/sites/indiawaterportal.org/files/Drinking\%2 OWater\%20Standards_IS\%2010500_1991_BIS.pdf)] and Bacteriological water testing kit (BWTK) (Sahota et al., 2010), developed in the 'Department of Microbiology, Punjab Agricultural University, Ludhiana, Punjab, India for total coliforms, faecal coliforms and Listeria spp..

\section{Isolation of Listeria spp.}

Aliquots of samples from positive Bateriological water testing kit (BWTK) (Sahota et al., 2010) were streaked on Listeria selective agar (Ceftazidime $2.0 \mathrm{mg} / 500 \mathrm{ml}$ and Amphotericin B $2.5 \mathrm{mg} / 500$ $\mathrm{ml}$ ) (Himedia Laboratories Pvt. Limited, Mumbai, India) and incubated at $37^{\circ} \mathrm{C}$ for 24 to $48 \mathrm{~h}$. Observed for typical colonies were blue with a yellow background (Rhamnose positive) or blue without a yellow background (Rhamnose negative).

\section{Biochemical confirmation}

Colonies suspected to be Listeria were characterized using Gram stain, catalase reaction, umbrella-shaped motility pattern using motility test medium, fermentation of mannitol, rhamnose and xylose performed according to Bergey's manual of systematic bacteriology (Seeliger and Jones, 1987).

\section{Scanning electron microscopy of bacterial cultures}

Samples were removed from agar plates and fixed with 3\% glutaraldehyde at $4^{\circ} \mathrm{C}$ overnight. Dehydration of the samples was then conducted by a series of $10,25,50,70,100 \%$ ethanol solutions. Using a Critical point dryer, the samples were dried further (CPD, Emitech). These samples were mounted on aluminum stubs and then coated with gold using a Sputter coater (Emitech). The samples were examined using a Hitachi (S 2700), scanning electron microscope.

\section{Serological identification of Listeria spp.}

HiListeria Latex test kit (HiMedia, Mumbai, India) was used for rapid identification of Listeria spp. from solid agar. The sensitised latex particles in solution/suspension containing antigen was used, against which the anti-serum was placed and observed for agglutination of the particles and compared with positive and negative control.

\section{Nucleic acid isolation}

Nucleic acid were isolated by lysis of bacteria in a solution containing $0.5 \%$ sodium dodecyl sulfate and $5 \mathrm{mg}$ of lysozyme per $\mathrm{ml}$, followed by extraction with phenol-chloroform (Hirono et al., 1992). Nucleic acid samples were precipitated with ethanol and 
dissolved in Tris-EDTA (TE) buffer (10 mM Tris chloride, $1 \mathrm{mM}$ EDTA [pH 8.0]). The nucleic acid content was quantified by determining the optical density (OD) at $260 \mathrm{~nm}\left(\mathrm{OD}_{260}\right)$ and was adjusted to give a final concentration of $200 \mu \mathrm{g} / \mathrm{ml}$ in TE buffer. Template DNA for PCR was prepared by further dilution in distilled water to a concentration of $2 \mu \mathrm{g} / \mathrm{ml}$.

Identification of Listeria spp. by polymerase chain reaction (PCR)

A $1.20 \mathrm{~kb}$ portion of the regulatory region of $16 \mathrm{~S}$ rRNA was amplified with the primers (forward primer 5'GGACCGGGGCTAATACCGAATGATAA-3') and reverse primer 5'TTCATGTAGGCGAGTTGCAGCCTA -3') (Wiedmann et al., 1993).

\section{Determination of virulence markers}

The isolates were tested for $\beta$-hemolytic activity on agar base supplemented with $5 \%$ sheep erythrocytes (Gerhardt et al., 1981) and Congo red dye uptake (Paniagua et al., 1990).

\section{Determination of multiple antibiotic resistance}

Pure cultures were grown in brain heart infusion broth for sensitivity testing. Mueller Hinton agar (Hi Media, Mumbai, India) was used (Bauer et al., 1966). A total of 30 different antibiotics (Hi-Media, Mumbai, India) were used. After enrichment in BHIB at $37^{\circ} \mathrm{C}$ for 6 to $8 \mathrm{~h}$, till the inoculum turbidity is achieved $\geq 0.10 \mathrm{D}$ at $620 \mathrm{~nm}$ or 0.5 Mcfarland standard, the cultures were streaked on Mueller Hinton agar plates using a cotton swab. With an antibiotic disc dispenser, ring containing the discs were placed on the agar surface. After $30 \mathrm{~min}$ of pre-diffusion time, the plates were incubated at $37^{\circ} \mathrm{C}$ for 18 to $24 \mathrm{~h}$. The results were recorded by measuring the inhibition zones according to the Clinical and Laboratory Standard Institute (CLSI, 2006). The multiple antibiotic resistance (MAR) index, when applied to a single isolate, is defined as $a / b$, where a represents the number of antibiotics to which the isolate was resistant and $b$ represents the number of antibiotics to which the isolate was exposed. MAR index higher than 0.2 identifies organisms that originate from high-risk sources of contamination, where antibiotics are often used. MAR indices less than or equal to 0.2 , identify isolates from environments where antibiotics are seldom or never used (Krumperman, 1985).

\section{Molecular characterization}

DNA was isolated from overnight grown bacterial cells in nutrient broth according to the standard methods (Sambrook et al., 2001). For amplification of $16 \mathrm{~S}$ rRNA gene, the following primers were used: forward primer 5'-AGAGTTTGATCCTGGCTCAG-3' and reverse primer 5'-ACGGGCGGTGTGTTC-3' (Weisberg et al., 1991). DNA amplification was performed with Genamp PCR sys-tem (Applied Biosystem, USA). 16S rDNA amplicon was gel eluted using GenElute gel extraction kit (Sigma-Aldrich, USA) and was ligated into the $\mathrm{pTZ57R/T}$ vector as per manufacturer's instruction (Fermentas, USA). Ligated plasmid was used to transform chemically competent Escherichia coli $\mathrm{DH} 5 \alpha$ by heat shock method. After screening of the positive clone, the sequence was generated by chain termination method using an Applied Biosystem automated sequencer (Delhi University South Campus, Delhi, India). The 16S rRNA gene sequence was compared with Ribosomal Database Project-II (RDP-II) (Cole et al., 2003) and with those from Gen-Bank using the BLASTN program (Altschul et al., 1997). The sequences were aligned using the CLUSTALW program (Thompson et al., 1997). The evolutionary distance was calculated by Kimura 2 para- meter, a phylogenetic tree was constructed by the neighbor-joining method. Bootstrap analysis was based on 1,000 replicates. The MEGA 4.0 package (Tamura et al., 2007) was used for all analyses. The 16S rRNA gene sequence determined in this study was deposited in GenBank of NCBI data library.

\section{Virulence studies and histopathology}

A group of five mice each were taken. They were deprived of drinking water for $24 \mathrm{~h}$, after that they were allowed to drink from aqeuous bacterial suspension containing about $1 \times 10^{8} \mathrm{cells} / \mathrm{ml}$, for $24 \mathrm{~h}$ of Listeria spp. The inocula were then withdrawn and the animals served with clean water after $24 \mathrm{~h}$ period. Those in control (five mice) were served with clean drinking water. Tissue samples, heart, liver, stomach, intestine, spleen and kidney were immediately removed from dead or killed mice, rinsed in isotonic solution and were fixed in formalin and embedded in paraffin, cut into $4 \mu \mathrm{m}$ sections and stained with hematoxylin-eosin.

\section{RESULTS AND DISCUSSION}

A total of 418 drinking water samples from three different water utilities Municipal Corporation (242), submersible pump (144) and hand pump (32) were analyzed for occurrence of Listeria spp. The positive BWTK was used for the isolation of Listeria spp. from drinking water. Out of 418 drinking water samples, $52.63 \%$ samples were positive for presence of Listeria spp. The growth of Listeria spp. was observed on Listeria selective supplement medium, colonies were blue with a yellow background. In nutrient broth, Listeria spp. produced uniform turbidity. The isolates observed under microscope were gram positive and rod shaped. The morphology was further confirmed by electron microscopy, which confirmed it to be rod shaped with round edges and approximate 1.31 to $2.28 \mu \mathrm{m}$ in size (Figure 1).

The isolates of Listeria spp. were further confirmed by HiListeria Latex test kit (HiMedia, Mumbai, India). Latex agglutination test uses the technique of absorbing antiserum for a specific antigen onto latex particles of uniform diameter, 0.8 microns. When the sensitised latex particles are placed in solution/suspension containing antigen against which the anti-serum is directed, agglutination of the particles occurs and is visible on inspection. Polyvalent antisera prepared against purified flagellin proteins from Listeria moonocytogenes and Listeria grayi, was used to coat latex particles. When mixed with a suspension containing Listeria species, the latex particles rapidly agglutinate to form visible clumps (Figure 2).

These 220 selected Listeria isolates were identified using PCR. The PCR primers for the specific detection of Listeria spp. was tested successfully under the reaction conditions described, that is, PCR products of desired size (1200 bp for Listeria spp.) was only obtained in reactions containing genomic DNA of the targeted serologically identified isolates (Figure 3 ). No product was detected when genomic DNA from other than the target organism was used. The PCR assay provides a more rapid means of accurate identification of Listeria 


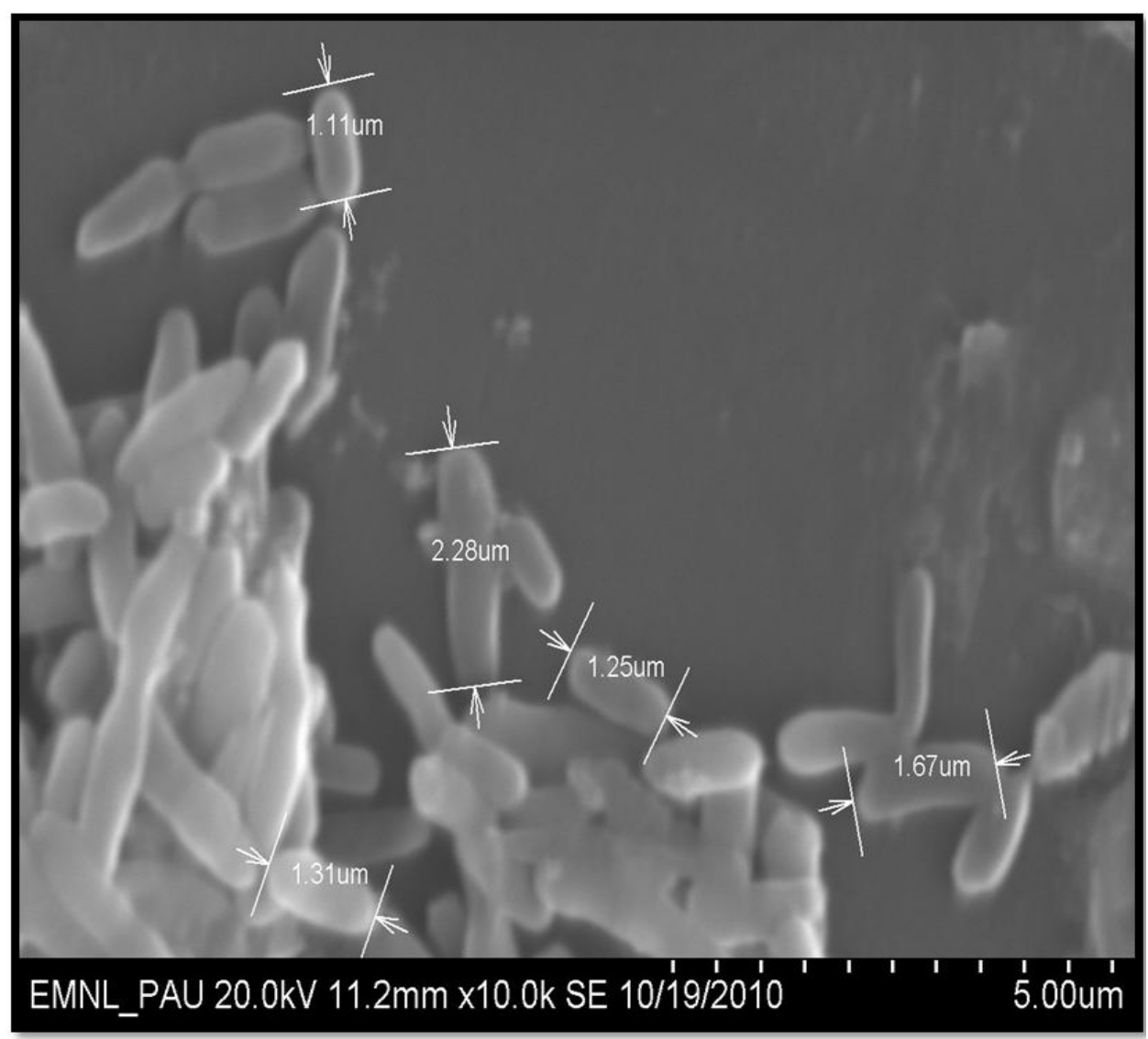

Figure 1. SEM images of Listeria spp. Length: 1.31 to $2.28 \mu \mathrm{M}$, width: $0.60 \mu \mathrm{M}$.

spp. than present standard methods of biotyping which are time-consuming and laborious. Use of the PCR would significantly reduce the time required to identify Listeria spp. isolates and can be used directly after primary selective culture of this organism. The entire test could be completed in $6 \mathrm{~h}$, including the DNA extraction step. The reason for occurrence of Listeria spp. in drinking water utilities may be poorly processed sewage effluents, malfunctioning of septic tanks, seepage from sanitary landfills, and failure of the disinfection and infilteration of contaminated water through cross connection in distribution system.

\section{Correlation between occurrence of $E$. coli and Listeria spp.}

Listeria spp. occurred in $58.67 \%$ of MC drinking water samples, $51.38 \%$ submersible pump drinking water samples and $12.5 \%$ of samples from hand pumps drinking water samples whereas, E. coli occurred in $53.71 \%$ of MC drinking water samples, $29.16 \%$ submersible pump drinking water samples and none of samples from hand pumps. There was no positive correlation between the occurrence of Listeria spp. and E. coli $\left(P<0.005 ; R^{2}=\right.$ $0.89)$. It is suggested that the dependence on classical pollution indicators like E. coli and culturable total and faecal coliforms may be misleading, as some of these indicators are reported to be more susceptible to disinfection than more resistant bacteria like Listeria. The implication of this is that a water supply may be adjudged fit and safe for human consumption based on the $E$. coli and coliform standards, whereas in actual sense, it may contain more deadly pathogens like Listeria. In addition, due to emphasis on the monitoring of classical pollution indicators as stated earlier, not much is being done with regards to the survival and molecular epidemiology of resistant isolates of Listeria species in drinking water, either as free or attached cells.

Thus the overall study revealed that, $E$. coli do not adequately reflect the occurrence of pathogens in drinking water, may be due to their relatively high susceptibility to disinfection. Thus, public health is not protected by using these common indicators.

\section{Determination of virulence marker of Listeria spp.}

Haemolysis is the key character to distinguish the pathogenic and non-pathogenic species of Listeria spp. It is used to distinguish the two species most frequently isolated that is, Listeria monocytogenes (haemolytic) and Lis- 

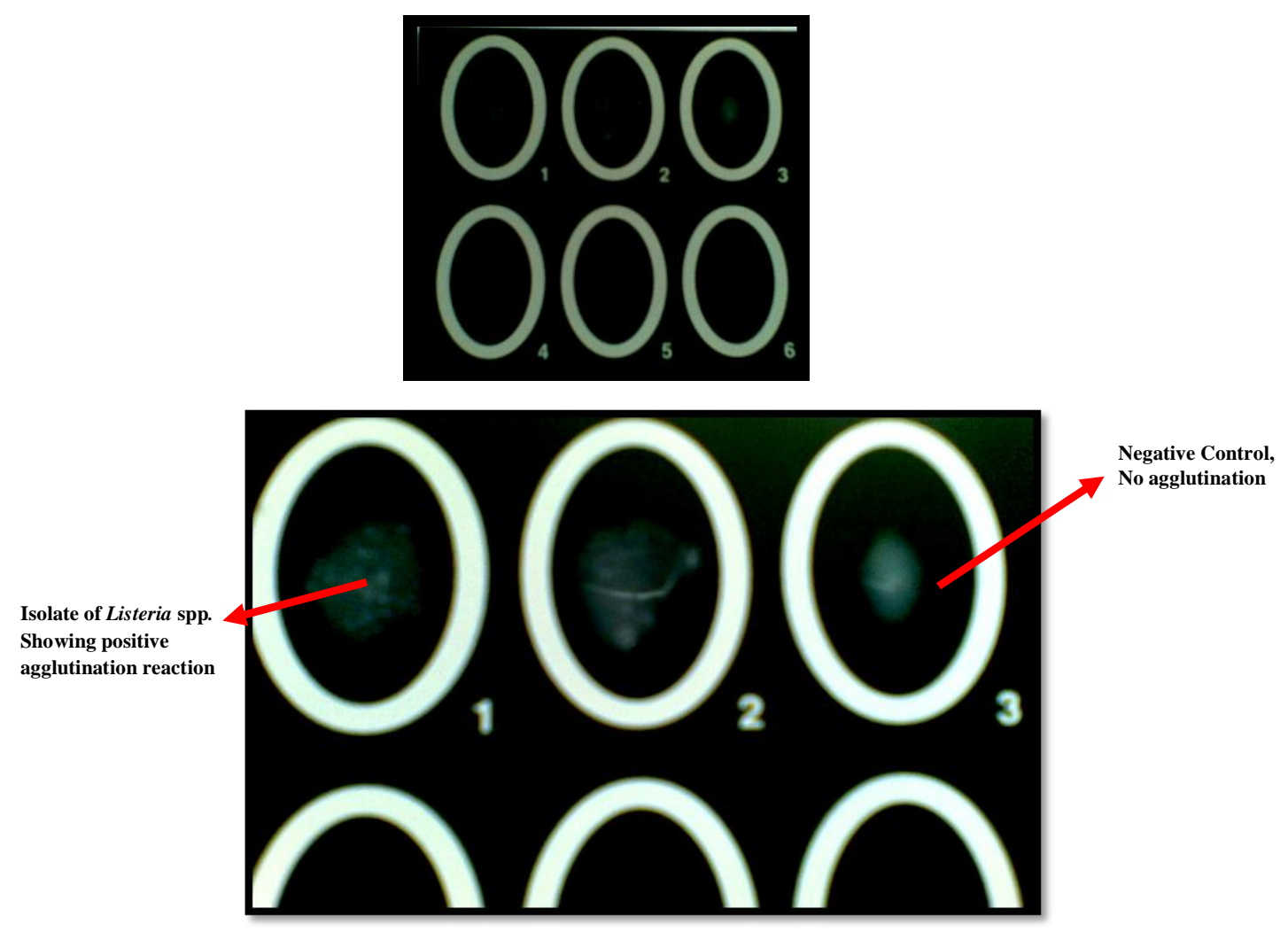

Figure 2. Serological Identification of Listeria spp.

teria innocua (non-haemolytic). Also, hemolysin has been associated with lecithinase production. In the study, it was found that all the serologically identified isolates of Listeria spp. were haemolytic on $5 \%$ sheep blood agar. These results highlight the pathogenic potential of Listeria spp. which poses a public health concern. It is also important to comment that the presence of any Listeria spp. may be indicative of poor hygiene and cross contamination scenarios which could favour the persistence of L. monocytogenes (Azevedo et al., 2005).

Virulence determinants are responsible for the establishment and maintenance of an infection in the host. Many plasmid-mediated properties have been used to distinguish between virulent and avirulent strains, including colony morphology (Mazigh et al.,1983), autoagglutination (Skurnik, 1984), detachment of cells in culture (Lassen and Kapperud, 1986), serum resistance (Pai and DeStephano, 1982), hydrophobicity (Lachica and Zink, 1984), and virulence characteristics in animals (Prpic et al., 1983). Most of the experimental procedures on virulence characterization are costly, time-consuming, complex and impractical for routine diagnostic use or in field laboratories.

The Congo red pigmentation assay provides a simple and efficient means of screening for virulence. The ability to take up dye is associated with the presence of a virulence plasmid. Uptake of Congo red dye has been shown to be a marker for virulence in several enteropathogenic and nonenteropathogenic bacteria. All the isolates of Listeria spp. were positive for Congo dye uptake; this finding suggests that all were potential enteric pathogens.

Nunes and Hofer (1994) also analyzed a total of 130 Listeria isolates in order to evaluate lecithinase production and capacity for Congo red adsorption as markers of pathogenicity. L. monocytogenes cultures present 51.8 and $88.8 \%$ positivity rates for Congo red adsorption and lecithinase production, respectively, whereas 80.8 and $100 \%$ of $L$. innocua cultures were negative for the two tests, respectively.

\section{Antibiotic susceptibility of Listeria spp}

A total of 220 isolates of Listeria spp. were isolated from 418 drinking water samples from three different water utilities, 142/242 Municipal Corporation, 74/144 submersible pump and $4 / 32$ hand pumps. These isolates were phenotyped, using antimicrobial susceptibility test against panel of 30 antibiotics. A total of $79.09 \%$ isolates were resistant to bacteriostatic antibiotic (chloramphenicol C/25 $\mathrm{mcg}$ and fusidic acid $\mathrm{Fc} / 10 \mathrm{mcg}$ ), lincosamides (lincomycin L/2 mcg and clindamycin $\mathrm{Cd} / 2 \mathrm{mcg}$ ), glycopeptide antibiotics (vancomycin $\mathrm{Va} / 30 / 20 \mathrm{mcg}$ and teicoplanin $\mathrm{Te} / 30 \mathrm{mcg}$ ), macrolides (erthromycin E/15 mcg), oxazollidone (Linezolid Lz/30 mcg), $73.18 \%$ Listerial isolates were resistant to quinolones (Co-trimoxazole $\mathrm{Co} / 25 \mathrm{mcg}$ ciprofloxacin $\mathrm{Cf} / 5 \mathrm{mcg}$ ) aminoglycosides (streptomycin 


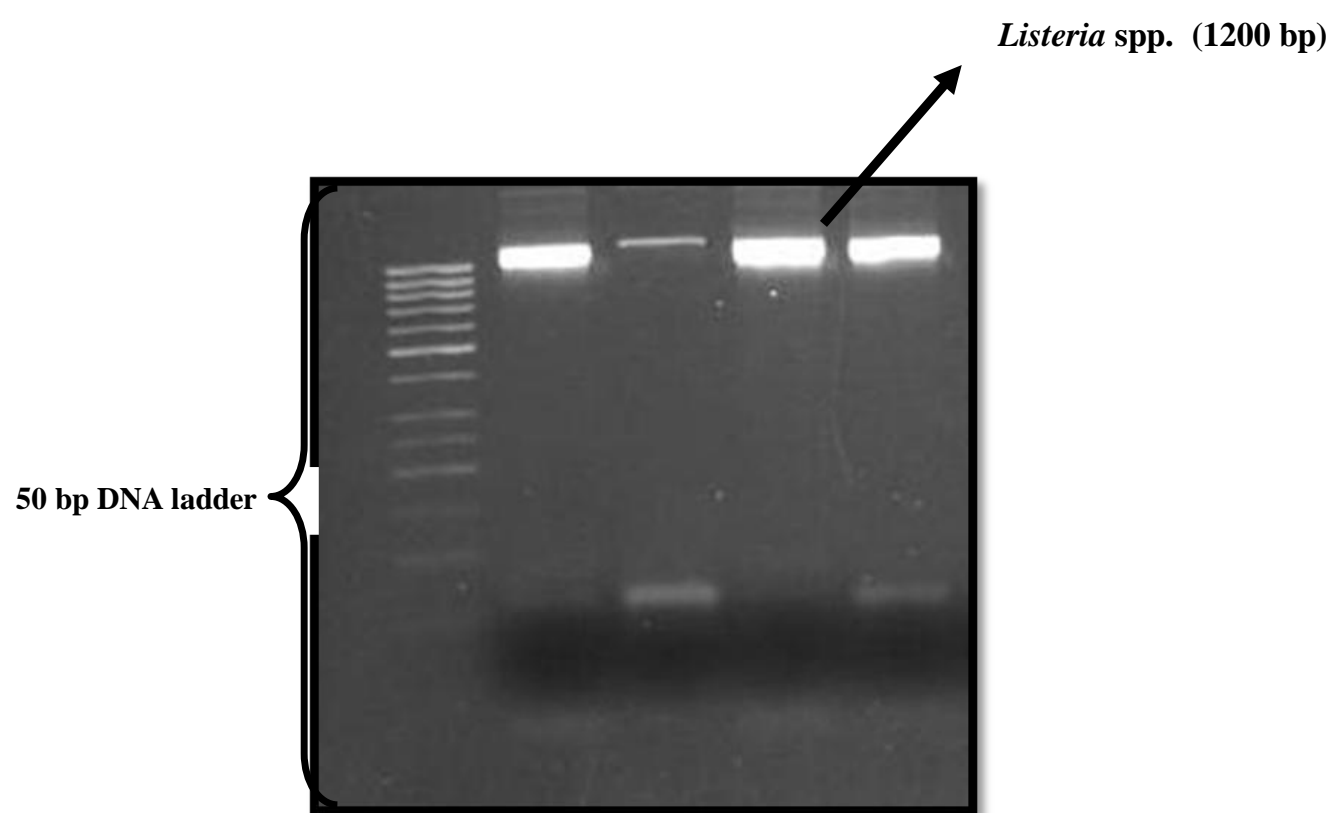

Figure 3. PCR with primers specific to $16 \mathrm{~S}$ rRNA gene of Listeria spp., PCR products were electrophoresed and visualized with ethidium bromide.

$\mathrm{S} / 10 \mathrm{mcg}$ ), monobactams (amoxyclav Ac/30 mcg), narrow spectrum beta-lactam antibiotic (ovacillin), penicillins (Penicillin, G (P) 10 units; methicillin, $\mathrm{M} / 5 \mathrm{mcg}$ and ampicilin, $\mathrm{A} / 10 / 10 \mathrm{mcg}$ ); tetracyclines (tetracycline, $\mathrm{T} / 30 \mathrm{mcg}$ ) and $69.55 \%$ isolates were resistant to cephalosporinsv (cefepime $\mathrm{Cpm} / 30 \mathrm{mcg}$, ceftazidime, $\mathrm{Ca} / 30 \mathrm{mcg}$; cefuroxime, $\mathrm{Cu} / 30 \mathrm{mcg}$; ceoxacillin, $\mathrm{Cx} / 1 \mathrm{mcg}$; cephalothin, $\mathrm{Ch} / 30 \mathrm{mcg}$; cephotaxime, Ce/30 mcg; cephoxitin, $\mathrm{Cn} / 30$ $\mathrm{mcg}$ ).

Sensitivity was only observed against vancomycin, $\mathrm{Va} / 30 \mathrm{mcg}$; erythromycin, E/15 mcg; ofloxacin, Of/30 mcg and gentamicin, G/10 mcg by $81.36 \%$ of total Listerial isolates tested. The most of bacterial isolate from drinking water was resistant to four out of thirty antibiotics tested. The zone of inhibition produced by different isolates was measured and there was non significant difference in the size $(\mathrm{mm})$ of zone produced by different isolates and all isolates showed same pattern of antibiotic susceptibility. MAR index for Listerial isolates is $0.86(>0.2)$.

The possible reason for high MAR may be contamination of drinking water by wastewater effluents which normally contain high concentration of antibiotics after treatment, thereby raising chances of antibiotic contaminants perturbing the microbial ecology; increasing proliferation of antibiotic resistant pathogens; and posing threats to human health as well as create challenges for the water industry on issues of water reuse and water resource planning (Daughton and Ternes, 1999). Multiple drug resistance in Listeria species have also been attributed to antimicrobial selective pressure and gene transfer mechanism between and amongst Listeria species and close relatives of the bacteria such as Enterococcus, Strepto- coccus and Staphylococcus species (Safdar and Armstrong, 2003). Donlan and Costerton (2002) also reported the acquisition of inherent resistance to antimicrobial agents by attached bacterial species.

The widespread use of antimicrobials in human and veterinary medicine, as well as in animal production, has accelerated the development of drug resistance in a variety of pathogenic bacteria. $L$. monocytogenes are important Gram-positive pathogens of public health concern. Antibiotic resistance in $L$. monocytogenes is mainly due to acquisition of three types of movable genetic elements: self-transferable plasmids, mobilizable plasmids, and conjugative transposons (Charpentier and Courvalin, 1999). Enterococci and Streptococci, in particular, represent a reservoir of resistance genes for $L$. monocytogenes. The gastrointestinal tract of humans is considered the most probable site where the acquisition by Listeria spp., of conjugative plasmids and transposons from Enterococcus-Streptococcus takes place (DoucetPopulaire et al., 1991).

\section{Molecular characterization}

One biochemically characterized isolate of Listeria spp., GP3 from drinking water was further subjected to $16 \mathrm{~S}$ rRNA gene sequencing. The $16 \mathrm{~S}$ rRNA gene sequence of GP3 Listeria spp. was compared with 16S rRNA gene sequence of DQ065845 Listeria seeligeri, FJ557241 Listeria rocourtiae, FJ774256 L. monocytogenes, FJ774247 L. innocua, DQ065843 L. seeligeri, X98529 Listeria ivanovii, FJ774232 L. innocua. On the basis of nucleotide homology and phylogenetic analysis, the isolate 


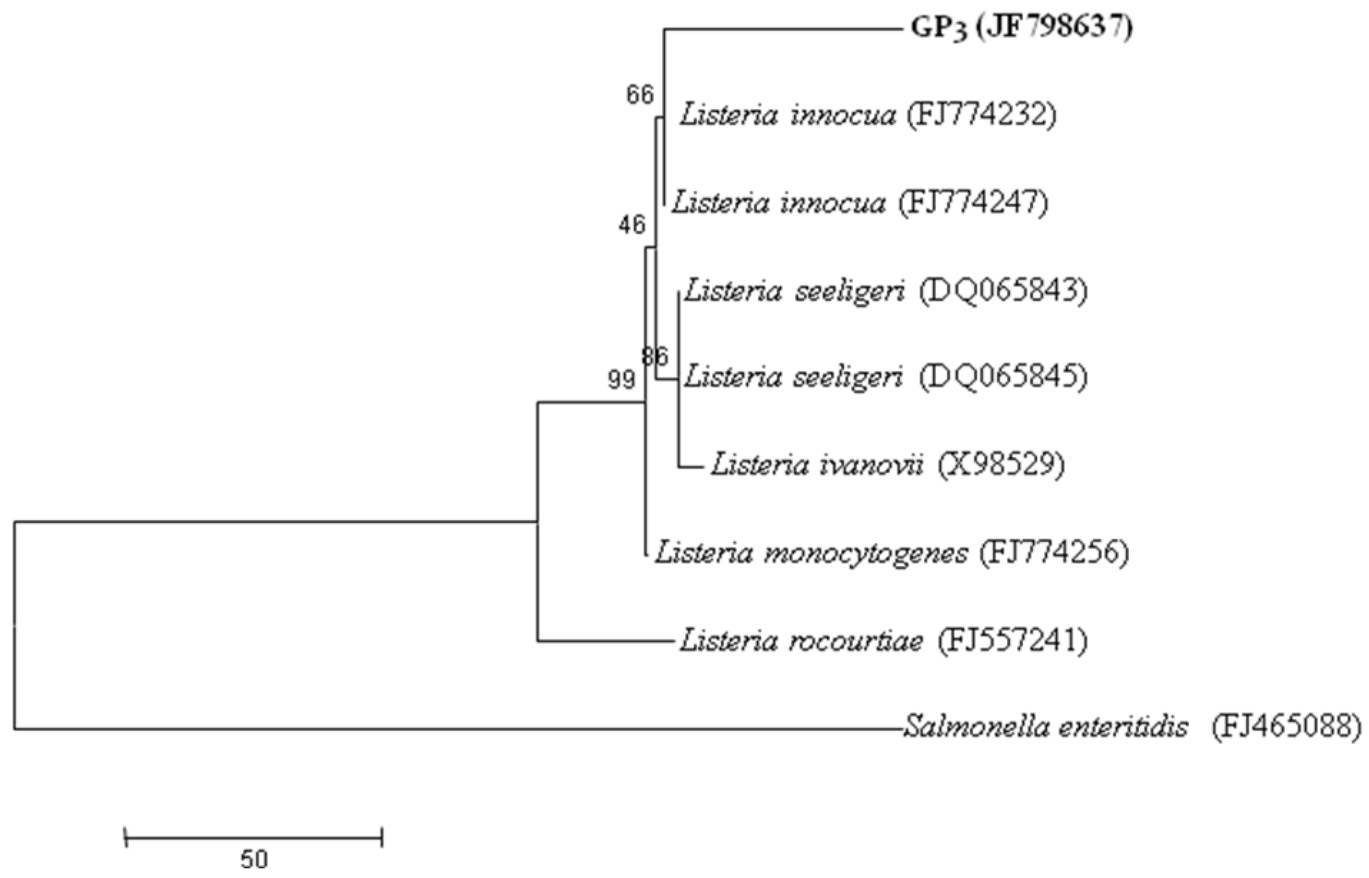

Figure 4. The phylogenetic dendrogram of Listeria spp. GP3 and related strains based on the $16 \mathrm{~S}$ rRNA sequence.

GP3 showed some percentage of homology with all the species of Listeria available in gene bank but Drancourt et al. (2000) recommended $\geq 99 \%$ sequence similarity of 16S rRNA gene sequences to the sequence deposited in DNA databases for a valid species designation, based on a large collection of environmental and clinical unidentifiable bacterial isolates. Finally, Stackebrandt and Ebers (2006) revised the former recommendations and suggested a higher 16S rRNA gene sequence similarity threshold range of 98.7 to $99 \%$ as the point at which DNADNA reassociation experiments should be mandatory for testing the genomic uniqueness of novel isolate(s). So, the isolate of Listeria spp. GP3 from drinking water could be new Listerial species, as it showed only some percentage of similarity with other Listerial isolates and hence grouped as Listeria spp. and, submitted to NCBI under an accession number JF798637 (Figure 4).

\section{Virulence studies and histopathology}

Listeriosis can manifest itself as sepsis, meningitis, encephalitis, intrauterine infections and spontaneous abortions in pregnant women. The onsets of these diseases are usually preceded by persistent fever or gastrointestinal symptoms such as nausea, vomiting and diarrhoea. $L$. monocytogenes is more prone to affect target populations such as pregnant women, newborn infants, immunocompromised individuals on corticosteroids, patients with cancer and other chronic diseases and the elderly.

In the present study, pathogenic potential of Listeria spp. form drinking water was investigated in the mice model. One biochemically and molecularly characterized isolate of Listeria spp. (GP 3) with accession number JF798637, isolated from drinking water was selected to study the course of infection in mice (five). Animals (mice) were deprived of drinking water for $24 \mathrm{~h}$ and then allowed to drink from aqeuous bacterial suspension containing $1 \times 10^{8} \mathrm{cells} / \mathrm{ml}$ of the Listeria spp., GP 3 for $24 \mathrm{~h}$. It was found that on the 10th day after inoculation of animals with the bacterial broth culture, signs of depression and isolation was observed. The faecal samples showed the presence of $1 \times 10^{15}$ cells $/ g$ of the o Listeria spp., (GP 3). The experimental mice died on the 12th (one), 15th (three), and 22nd (one) days, respectively of post inoculation. Tissues from the intestine, liver, kidney and lungs were removed at postmortem of the infected animals (carcasses).

Histopathological examination of liver revealed vacuolar and granular degeneration of hepatocytes, focal areas of mononuclear cell infilteration in periportal area and necrosis of focal area (Figure 5). The intestine showed sloughing of mucosal lining epithelium, infilteration of mononuclear cell in lamina propria and hypertrophy of villi (Figure 6). The lungs revealed oedema, haemorrhage and congestion (Figure 7).

The kidney showed coagulated type of necrosis, mild granular degeneration of tubular epithelium, increase in cellularity in the glomeruli and in interstitium, decrease in urinary space, and swollen glomeruli (Figure 8). The bacterial colonies in myocardium, focal infilteration of mononuclear cells, degeneration and necrosis of myocardium, valvular endocarditis and congestion was observed in 

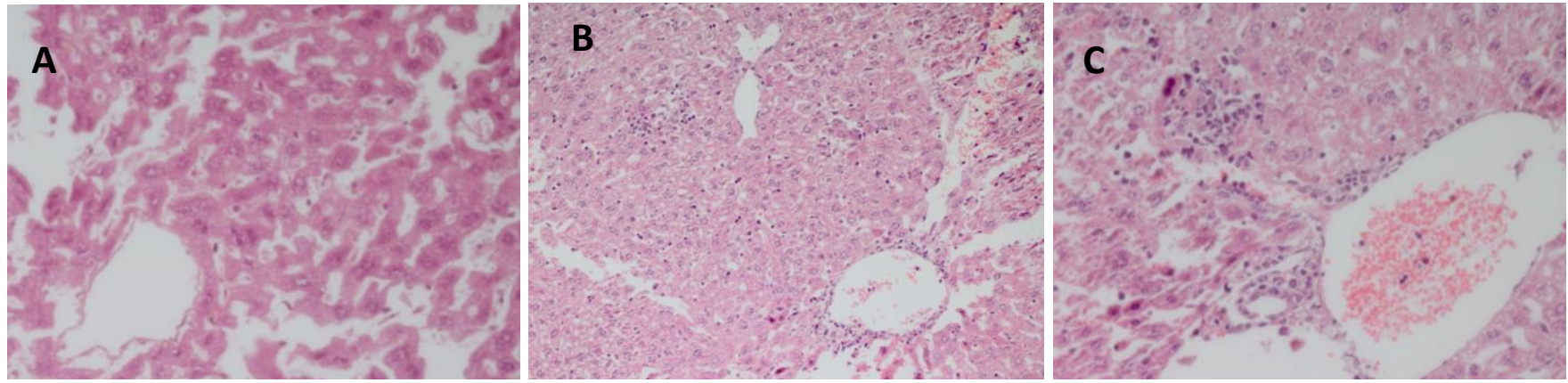

Figure 5. A. Histological tissue of mice (liver) infected with Listeria spp. showed vacuolar and granular degeneration of hepatocytes (40x) ( $\mathrm{H}$ and $\mathrm{E}$ stain). B. Histological tissue of mice (liver) infected with Listeria spp. showed granular degeneration of hepatocytes, focal areas of mononuclear cell infilteration in periportal area and necrosis of focal area (20x) (H and E stain). C. Histological tissue of mice (liver) infected with Listeria spp. showed granular degeneration of hepatocytes, focal areas of mononuclear cell infilteration in periportal area and necrosis of focal area $(20 x)$ ( $H$ and $E$ stain).
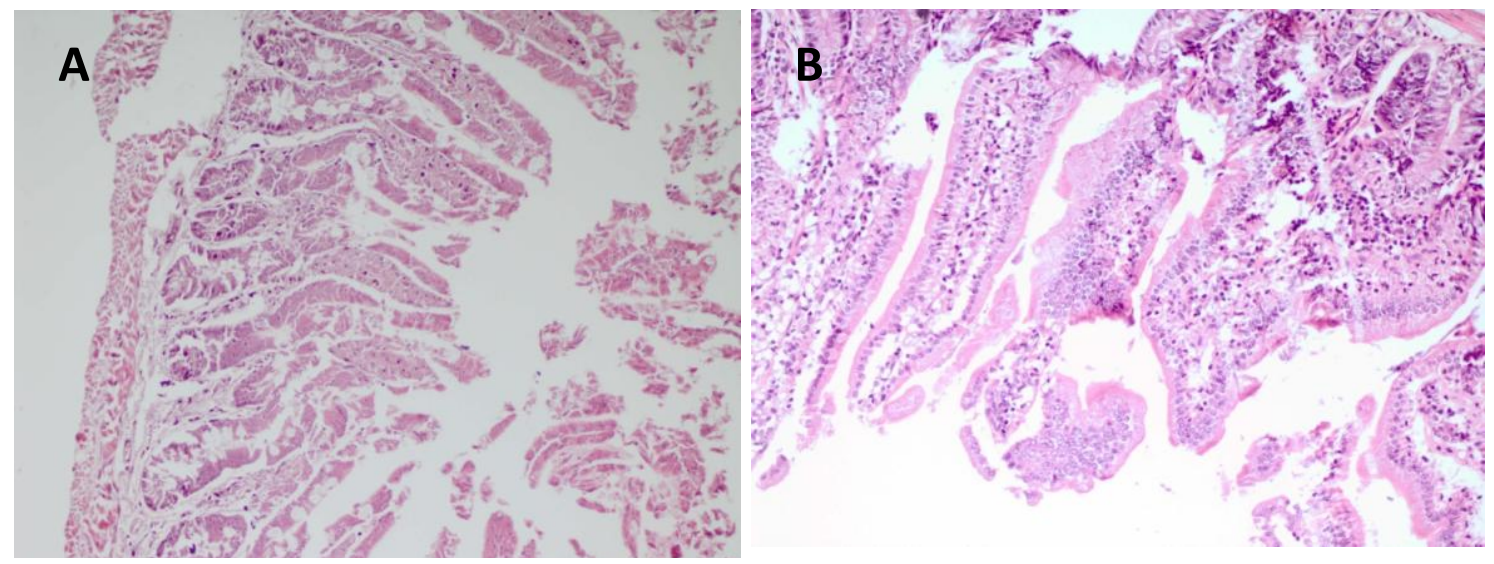

Figure 6. A. Histological tissue of mice (intestine) infected with Listeria spp. showed sloughing of mucosal lining epithelium, infilteration of mononuclear cell in lamina propria and hypertrophy of villi $(20 \times)(H$ and $E$ stain). B. Histological tissue of mice (intestine) infected with Listeria spp. showed hypertrophy of villi $(20 \times)(H$ and $E$ stain).

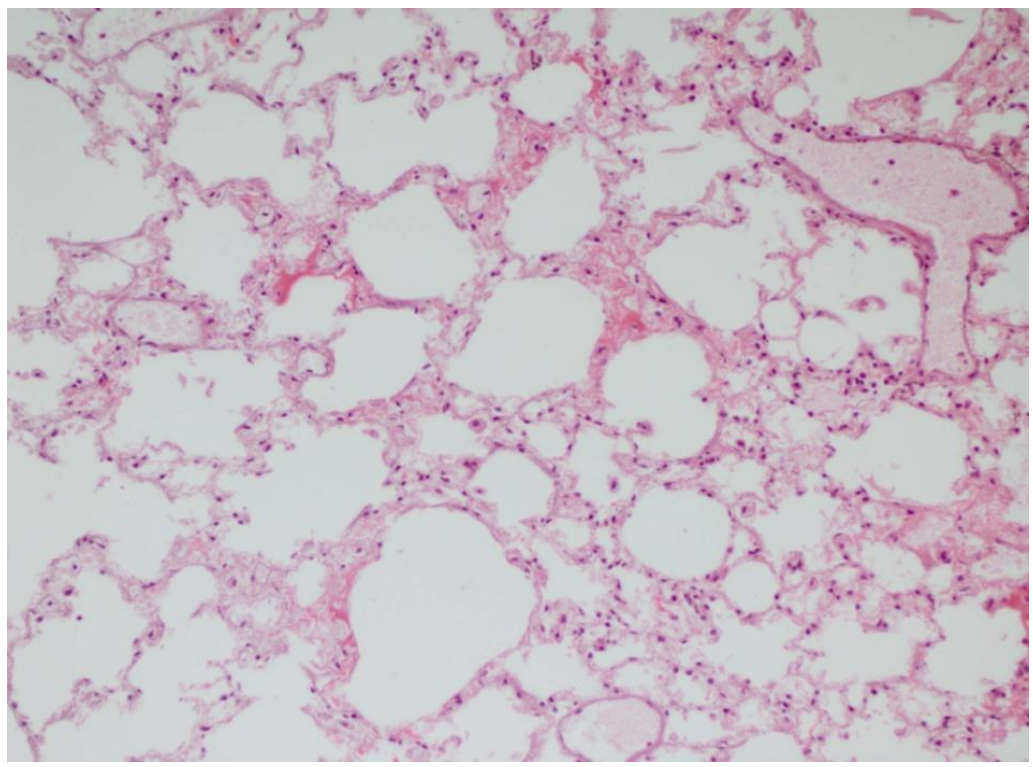

Figure 7. Histological tissue of mice (lungs) infected with Listeria spp. showed oedema, haemorrhage and congestion (20x) (H and $E$ stain). 

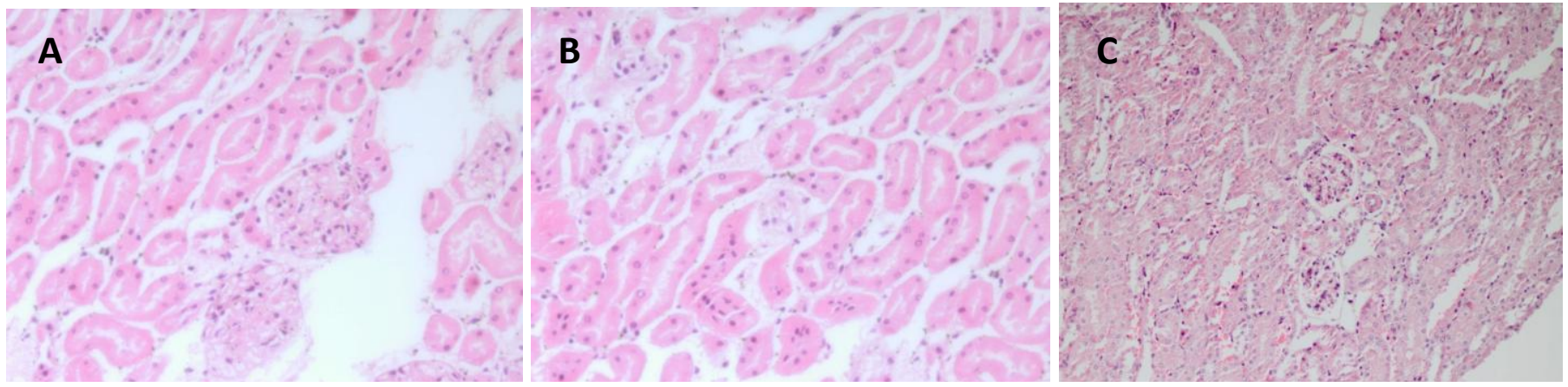

Figure 8. A. Histological tissue of mice (kidney) infected with Listeria spp. showed increase in cellularity in the glomeruli, decrease in urinary space and glomeruli swollen (40x) ( $\mathrm{H}$ and $\mathrm{E}$ stain). B. Histological tissue of mice (kidney) infected with Listeria spp. showed coagulated type of necrosis (40x) ( $\mathrm{H}$ and $\mathrm{E}$ stain). C. Histological tissue of mice (kidney) infected with Listeria spp. showed mild granular degeneration of tubular epithelium, increase in cellularity in interstitium and glomeruli.(20x) (H and E stain).
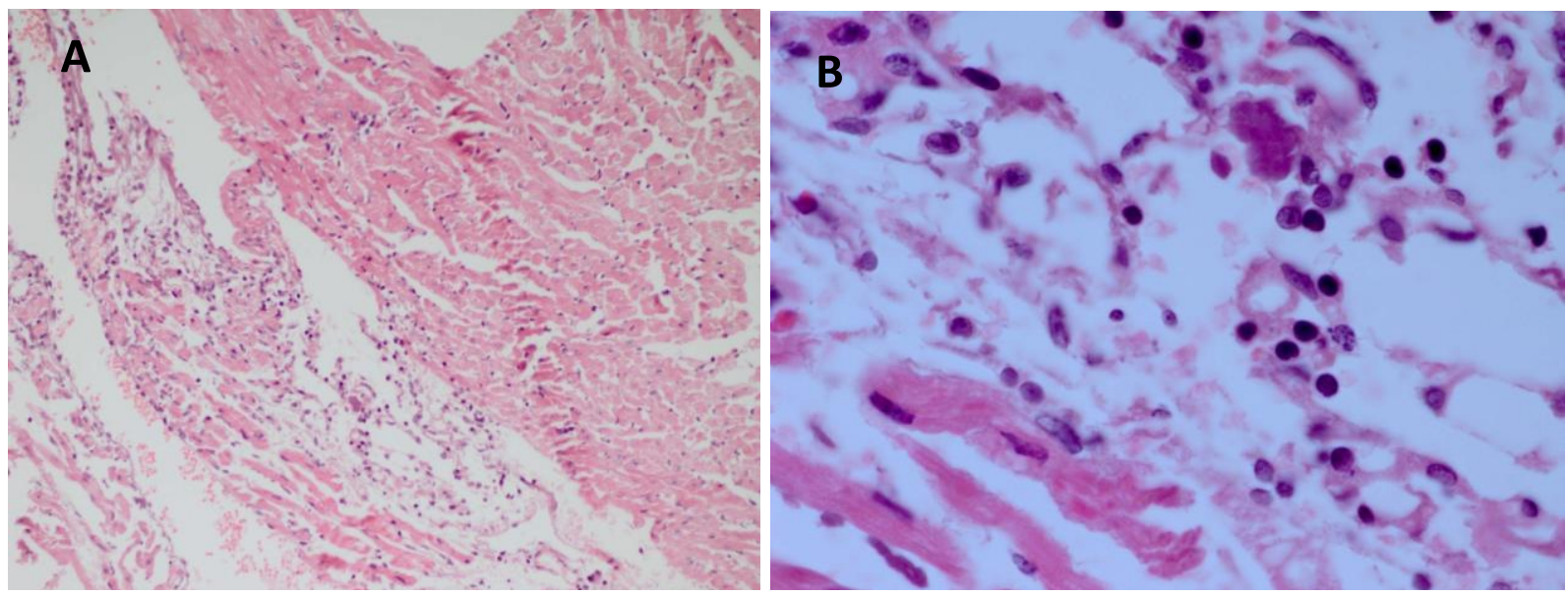

Figure 9. A. Histological tissue of mice (Heart) infected with Listeria spp. showed bacterial colonies in myocardium, focal infilteration of mononuclear cells, degeneration and necrosis of myocardium, valvular endocarditis and congestion (20x) ( $\mathrm{H}$ and $\mathrm{E}$ stain). B. Histological tissue of mice heart infected with Listeria spp. showed revealed bacterial colonies in heart $(100 \times)$ ( $\mathrm{H}$ and $\mathrm{E}$ stain).

\section{heart (Figure 9).}

Moshtaghi et al. (2006) also reported pathological changes in the liver, spleen, brain, kidneys and intestine. Histopathological examination of the liver revealed congestion and pyogranulomas consisting of necrosed hepatic cells, macrophages and neutrophils. In kidneys, histopathological changes were characterized by the presence of focal interstitial nephritis, focal areas of neutrophils and lymphocytes in interstitial tissue and atrophy of tubules. Similarly, Fowler et al. (1988) compared virulence of the five species of Listeria spp. in C57BL/6 and $\mathrm{BALB} / \mathrm{c}$ mice in terms of histological changes in mouse livers. L. seeligeri AB2 produced-mild PMN infiltration, $L$. monocytogenes SLCC 2540 produced micro-abscess and hepatocyte degeneration, L. ivanovii W 5379 produced micro- abscess 'and hepatocite degeneration and $L$. ivanovii W 5379 produced residual granuloma in the liver.

The incubation period for listeriosis is variable, and ranges from three to 70 days, with the median incubation period being three weeks. It can be observed from this work that the strain of Listeria spp. isolated from drinking water has the same incubation period in the laboratory animals studied (12 to 22 days). This could be due to their near similar physiologic disposition as in man.

\section{Conclusion}

This is the first study conducted in Ludhiana city, Punjab, India showing the occurrence of Listeria spp. in $52.63 \%$ of drinking water samples. Discrepancies have been observed in terms of the occurrence of faecal indicators and emerging pathogens pathogens. The use of faecal indicator $(E$. coli) raises questions regarding their reliability in assessing the bacteriological quality of water, particularly because of their poor correlation with pathogenic microorganisms. Update and new culture methods should be included in standard methods for monitoring, sampling and analysis of these emerging pathogens. Ensuring 
the appropriate level of chlorination can guarantee the water quality.

\section{ACKNOWLEDGEMENT}

The financial assistance provided by Ministry of Science and Technology, Department of Science and Technology (DST, under water technology initiatives), New Delhi, India, for the project "Biomonitoring of indicator and emerging pathogens in drinking water and remedial measures" is duly acknowledged.

\section{REFERENCES}

Arslan S, Ozdemir F (2008). Prevalence and antimicrobial resistance of Listeria spp. in homemade white cheese. Food Control, 19: 360-363

Altschul SF, Madden TL, Schaffer AA, Zhang S, Zhang Z, Miller W, Lipman D J (1997). Gapped BLAST: a new generation of protein database search programs. Nucleic Acids Res. 25:3389-02.

American Public Health Association (APHA) (1989). Standard Methods for the examination of Water and Wastewater, $18^{\text {th }}$ ed., American Public Health Association, Washington, D.C.

Azevedo I, Regalo M, Mena C, Almeida G (2005).Incidences of Listeria spp. in domestic refrigerators in Portugal. Food Control, 16:121-124

Bauer AW, Kirby WMM, Sherris JC, Truck M (1966). Antibiotic susceptibility testing by a standard single disc method. Am. J. Clin. Path. 36:493-496.

Clinical and Laboratory Standards Institute (CLSI) (2006).Performance standards for antimicrobial disk susceptibility tests; approved standard. Wayne, USA.

Cole JR, Chai B, Marsh TL, Farris RJ, Wang Q, Kulam SA (2003). The ribosomal database project (RDP-II): previewing a new autoaligner that allow a regular updates and the now prokaryotic taxonomy. Nucleic Acids Res. 31:442-43.

Conter M, Paludi D, Zanardi E, Ghidini S, Vergara A, lanieri A (2009). Characterization of antimicrobial resistance of foodborne Listeria monocytogenes. Int. J. Food Microbiol. 128: 497-500

Daughton CG, Ternes TA (1999). Pharmaceuticals and personal care products in the environment: agents of subtle change? Environ. Health Persp. 107:907-38.

Donlan RM, Costerton JW (2002). Biofilms: survival mechanism of clinically relevant Microorganisms. Clin. Microbiol. Rev. 15:167-93.

Drancourt M, Bollet C, Carlioz A, Martelin R, Gayral J P and Raoult D (2000). 16S ribosomal DNA sequence analysis of a large collection of environmental and clinical unidentifiable bacterial isolates. J Clin Microbiol 38: 3623-30.

Fowler T, Macgowan AP, Postlethwaite R (1988). Virulence of Listeria spp.: course of infection in resistant and susceptible mice. J. Med. Microbiol. 27:131-40.

Gerhardt P, Murray RGE, Castilow RN, Nester EW,Wood A, Krieg NR, Phillips GB (1981). Manual of methods for general bacteriology. American Society for Microbiology, Washington, DC

Hirono I, Aoki T, Asao T, Kazakis S (1992). Nucleotide sequence and characterization of hemolysin genes from Aeromonas hydrophila and Aeromonas sorbia. Microb. pathog.13, 433-446.

Kirkan S, Goksoy E O, Kaya O (2006). Detection of Listeria monocytogenes by using PCR in Helix pomatia. Turk. J. Vet. Anim. Sci. 30:375-380.

Krumperman PH (1985). Multiple antibiotic indexing of E. coli to identify high-risk sources of fecal contamination of foods. Appl. Environ. Microbiol. 46:165-170.

Lachica RV, Zink DL (1984). Determination of plasmid associated hydrophobicity of Yersinia enterocolitica by a latex particle agglutination test. J. Clin. Microbiol. 19:660-63.

Lassen J, Kapperud G (1986). Serotype-related HEp-2 cell interaction of Yersinia enterocolitica. Infect Immun 52:85-89.
Li Q, Sherwood JS, Logue C M (2007). Antimicrobial resistance of Listeria spp. recovered from processed bison. Lett. Appl. Microbiol. 44:86-91.

Lunden J, Tolvanen R, Korkeala $\mathrm{H}$ (2004). Human listeriosis outbreaks linked to dairy products in Europe. J. Dairy. Sci. 87:6-11.

Maijala R, Lyytikainen O, Johansson T, Autio T, Aalto T, Haavisto L, Honkanen-Buzalski T (2001). Exposure of Listeria monocytogenes within an epidemic caused by butter in Finland. Int. J. Food Microbiol. 70:97-109.

Mazigh D, Alonso JM, Mollaret HH (1983). Simple method for demonstration of differential colony morphology of plasmidassociated virulent clones of Yersinia enterocolitica. J. Clin. Microbiol. 17:555-57.

Moshtaghi H, Arabi M, Karimi I (2006). Histopathlogy and pathogenesis of listeriosis caused by Listeria monocytogenes isolated from raw milk in mice. Pakistan. J. Biol. Sci. 9:2181- 83

Pai C H, DeStephano L (1982). Serum resistanceassociated with virulence in Yersinia enterocolitica. Infect. Immun. 35:605-611.

Paniagua C, Rivero O, Anguita J, Naharro G (1990). Pathogenicity factors and virulence for rainbow trout (Salmo gairdneri) of motile Aeromonas spp. isolates from river. J. Clin. Microbiol. 28:350- 55.

Prpic JK, Robins-Browne RM, Davey RB (1983). Differentiation between virulent and avirulent Yersinia enterocolitica isolates by using Congo red agar. J. Clin. Microbiol. 18:486-490.

Safdar A, Armstrong D (2003). Antimicrobial activities against 84 Listeria monocytogenes isolates from patients with systemic listeriosis at a comprehensive cancer center (1955-1997). J. Clin. Microbiol. 41:483-85.

Sahota P, Pandove G , Achal V and Vikal Y (2010). Evaluation of a BWTK for simultaneous enumeration of Total coliform, E.coli and emerging pathogens from drinking water: comparison with standard MPN method. Water Sci. Technol. 62: 676-683.

Sambrook J, Russell D W (2001). Molecular Cloning: A Laboratory Manual, $3^{\text {rd }}$ edn. Cold Spring Harbor Laboratory Press, Cold Spring Harbor, NY.

Seeliger HPR and Jones D (1987). Listeria.In:Holt, J.G.(Ed.) Bergey's Manual of Systematic Bacteriology, $9^{\text {th }}$ Edition.Williams \&Wilikins, Baltimore MD.

Skurnik M, Bolin I, Heikkinen H, Piha S, Wolf-Watz H (1984). Virulence plasmid-associated autoagglutination in Yersinia spp. J. Bacteriol. 158:1033-036.

Stackebrandt E, Ebers J (2006). Taxonomic parameters revisited: tarnished gold standards. Microbiol Today 33:152-55.

Tamura K, Dudley J, Nei M, Kumar S (2007). MEGA4: molecular evolutionary genetics analysis (MEGA) software version 4.0. Mol. Biol. Evol. 24:1596- 599.

Thompson JD, Gibson TJ, Plewniale F, Jeanmaugin F, Higgins DG (1997). The CLUSTAL $X$ windows interface flexible strategies for multiple sequence alignment aided by quality analysis tools. Nucleic Acids Res. 25:4876- 882

Wiedmann M, Barany F and Batt CA (1993). Detection of Listeria monocytogenes with a nonisotopic polymerase chain reactioncoupled ligase chain reaction assay. Appl. Environ. Microbiol. 59:2743- 745

Weisberg WA, Barns SM, Pelletier DA, Lane DJ (1991). 16S rDNA amplification for phylogenetic study. J. Bacteriol. 173:697-03.

WHO (2004). Guidelines for Drinking-Water Quality. $3^{\text {rd }}$ Edn., Incorporation First and Second Addenda. Vol. 1, World Health Organisation, Geneva.

www.wateraid.org. 